\title{
IMPLEMENTASI KEWENANGAN BADAN KEHORMATAN DPRD DALAM PENEGAKAN KODE ETIK TERHADAP ANGGOTA DPRD DI PROVINSI NTB
}

\author{
AUTHORITY IMPLEMENTATION OF BODY OF HONOUR ON \\ REGIONAL HOUSE OF REPRESENTATIVE ON THE ENFORCEMENT \\ OF ETHICAL CODE TOWARD MEMBERS OF THE REGIONAL \\ REPRESENTATIVES OF HOUSE OF REPRESENTATIVE OF NTB \\ PROVINCE
}

\author{
Nurmadiah \\ Universitas Mataram program Magister Ilmu hukum \\ email : nurma_zakariah@yahoo.co.id
}

Naskah diterima : 22/09/2016; revisi : 22/12/2016; disetujui : 30/12/2016

\begin{abstract}
This research is meant to know how is the implementation of Body of honour's authority in enforcement of ethical code of regional house of representative of NTB province; to know the obstacle faced by Body of Honour of regional house of representative of NTB province in enforcement of ethical code. This research is a normative empirical research, Method of approach used in this research are statute approach, conceptual approach and sociological approach. Data collected with interview and library/ literature study. Data analysed qualitatively.

Based on result of the research known that; (1) the implementation of Body of honour's authority in enforcement of ethical code of regional house of representative of NTB province is not optimal, large authority do not keep Body of Honour have enough power to implement its authority, because it must have to report case of violations on ethical code to the chairman of regional house of representative; (2) the obstacle faced by regional house of representative of NTB province in enforcement of ethical code are: restriction on rule of proceedings; influence from the outside on the authority of Body of Honour; lack of support from the society.
\end{abstract}

Keywords ; Authority; Body of Honour; ethical code; regional house of representatives

Abstrak

Penelitian ini bertujuan untuk mengetahui bagaimana implementasi kewenangan Badan Kehormatan DPRD dalam penegakan kode etik anggota DPRD di Provinsi NTB; untuk mengetahui Kendala-kendala yang dihadapi Badan Kehormatan DPRD dalam penegakan etik anggota DPRD di Provinsi NTB. Penelitian ini merupakan penelitian hukum empiris, Metode pendekatan yang digunakan dalam penelitian ini adalah: Pendekatan peraturan perundang-undangan (statute approach), Pendekatan konseptual (conceptual approach), Pendekatan sosiologis (sociological approach). Tehnik pengumpulan data dilakukan dengan wawancara dan kepustakaan. Analisis data dilakukan secara kualitatif. Berdasarkan hasil penelitian diketahui (1) Implementasi kewenangan Badan Kehormatan dalam menegakkan Kode etik anggota DPRD Provinsi NTB belum maksimal kewenangan yang besar tidak membuat Badan Kehormatan cukup kuat dalam melaksanakan kewenangannya, karena Badan Kehormatan harus terlebih dahulu melaporkan kasus pelanggaran etika kepada Pimpinan DPRD dan Fraksi. (2) kendala Badan Kehormatan dalam melaksanakan tugasnya yaitu adanya pembatasan dalam peraturan tata beracara; adanya pengaruh dari luar terhadap kewenangan BK; dan Kurangnya dukungan dari masyarakat,

Kata kunci: kewenangan; badan kehormatan; kode etik, DPRD 


\section{PENDAHULUAN}

DPRD MERUPAKAn Unsur penyelenggara pemerintahan daerah dan juga sebagai wahana demokrasi dalam penyelenggaraan pemerintahan daerah. Untuk menjalankan fungsi, tugas serta wewenang nya baik DPR maupun DPRD memiliki beberapa unit kerja yang biasa disebut dengan "alat kelengkapan". Alat-alat kelengkapan DPR/ DPRD tersebut ada yang bersifat tetap dan sementara. Salah satu alat kelengkapan DPR/DPRD yang bersifat tetap adalah Badan Kehormatan. Sebagai Salah satu alat kelengkapan DPRD yang bersifat tetap Badan Kehormatan dibentuk untuk melaksanakan dan menegakkan kode etik DPRD dan ditetapkan dengan keputusan DPRD. Anggota badan kehormatan berjumlah 5 (lima) orang yang dipilih dari dan oleh anggota DPRD atas usulan masingmasing fraksi dan ditetapkan dalam rapat paripurna.

Badan Kehormatan sebagai lembaga pengawas DPRD diharapkan dapat meminimalisir pelanggaran etik di DPRD yang sering terjadi belakangan ini salah satunya yaitu yang terkait dengan konflik sesama anggota yang kerap terjadi serta melibatkan media, karena hal tersebut akan berdampak besar bagi citra DPRD di mata rakyat. Sebagai lembaga legislasi yang mewakili rakyat sudah seharusnya anggota DPRD mengutamakan kepentingan dan aspirasi rakyat bukan sebaliknya mengurangi kepercayaan rakyat dengan cara saling menjatuhkan di media.

Seperti Pada Kamis 3 Maret 2016, Wakil Ketua DPRD Nusa Tenggara Barat MH mengatakan di depan wartawan akan melaporkan sesama koleganya di DPRD, MF ke Badan Kehormatan, dikarenakan MF menudingnya sebagai pembohong di sejumlah media. Selain itu, MF juga pernah dilaporkan ke Badan Kehormatan oleh Ketua Badan Pembentukan Perda (Baperda) NTB, B.IR, MF dilaporkan ke Badan Kehormatan lantaran pernyataan $\mathrm{MF}$ di salah satu media yang menyudutkan Baperda DPRD NTB.

Berdasarkan latarbelakang masalah di atas, maka dapat dirumuskan permasalahannya sebagai berikut:

Bagaimana implementasi kewenangan Badan Kehormatan DPRD dalam penegakan kode etik anggota DPRD Provinsi NTB?,

Kendala-kendala apa saja yang dihadapi Badan Kehormatan DPRD dalam penegakan etik anggota DPRD Provinsi NTB?

Penelitian ini adalah penelitian hukum empiris, yaitu penelitian yang mengkaji keberlakuan nya hukum (law in action) sebagai norma yang berlaku di dalam kehidupan bermasyarakat. Atau penelitian yang objek kajiannya mengenai perilaku masyarakat. ${ }^{1}$

Adapun Metode pendekatan yang digunakan adalah Pendekatan peraturan perundang-undangan (statute approach) yakni dengan mengkaji peraturan perundang-undangan, asas-asas, maupun norma-norma hukum yang berkaitan dengan rumusan penelitian. Pendekatan konseptual (conceptual approach) yakni pendekatan yang dilakukan dengan mengkaji konsep-konsep dan pandangan para ahli yang berkaitan dengan tugas dan kewenangan badan kehormatan DPRD dalam penegakan kode etik anggota DPRD Studi di DPRD Provinsi NTB. Pendekatan sosiologis (sociological approach) digunakan untuk mengetahui bagaimana aturan hukum dilaksanakan berkaitan dengan tugas dan kewenangan badan kehormatan DPRD dalam penegakan kode etik anggota DPRD Studi di DPRD Provinsi NTB.

\section{PEMBAHASAN}

Adapun Teori hukum yang akan digunakan dalam membahas dan mengkaji permasalahan dalam penelitian ini adalah:

${ }^{1}$ Mukti Fajar dan Yulianto achmad, Dualisme Penelitian Hukum Normatif dan Empiris, Pustaka Pelajar, Yogyakarta, 2010, hlm.51 


\section{Teori Negara Hukum}

Dalam Pasal 1 ayat (3) UUD 1945 Negara Indonesia adalah Negara hukum. Negara hukum sebagaimana yang diungkapkan oleh para ahli hukum Eropa Kontinental seperti Immanuel Kant dan Frederich Julius Stahl Menyebut dengan istilah rechstaat, sedangkan A. V. Dicey yang merupakan ahli hukum Anglo Saxon menyebut dengan istilah rule of law. Julius Stahl menyatakan Unsur-unsur dari Rechstaat adalah: ${ }^{2}$

a. Perlindungan hak-hak asasi manusia;

b. Pemisahan atau pembagian kekuasaan;

c. Pemerintahan berdasarkan peraturan perundang-undangan;

d. Peradilanadministrasidalamperselisihan.

Dalam konstitusi ditegaskan bahwa Negara Indonesia adalah Negara Hukum (rechstaat). ${ }^{3}$ Adapun ciri-ciri rechstaat antara lain: ${ }^{4}$

a. Adanya Undang-undang Dasar atau konstitusiyangmemuatketentuantertulis tentang hubungan antara penguasa dan rakyat

b. Adanya pembagian kekuasaan dengan negara

c. Diakui dan dilindunginya hak-hak kebebasan rakyat.

Negara hukum merupakan dasar suatu negara dalam melaksanakan tindakan yang menempatkan asas legalitas sebagai dasar tindakan dari suatu negara. Dalam melaksanakan pemerintahan Indonesia yang menggambarkan negara hukum haruslah sesuai dengan unsur-unsur yang telah dikemukakan diatas, sehingga nantinya pemerintah dalam melaksanakan tindakannya dalam rangka menyeleng-

\footnotetext{
${ }^{2}$ Miriam Budiarjo, Dasar-Dasar ilmu Politik, Edisi Revisi Cetakan Keempat, PT Gramedia Pustaka Utama, Jakarta, 2010, hlm. 113

${ }^{3}$ Jimly Asshiddiqie, Konstitusi dan Konstitusionalisme Indonesia, Sinar Grafika, Jakarta, 2010, hlm. 57

${ }^{4}$ Ni'matul Huda, Op. cit, hlm. 74
}

garakan pemerintahan yang baik memiliki dasar pembenaran, maupun ketika tindakan nya itu menyimpang dapat diajukan suatu upaya hukum sebagaimana unsur dari negara hukum lainnya yaitu peradilan administrasi, sebagai suatu lembaga yang diberikan kepada masyarakat untuk memperoleh keadilan ketika berhadapan dengan negara.

\section{Teori Kewenangan}

Secara teoritis, kewenangan yang bersumber dari perundang-undangan diperoleh melalui tiga cara yaitu atribusi, delegasi, dan mandat. ${ }^{5}$ Kewenangan yang sumbernya dari peraturan perundangundangan disebut dengan kewenangan konstitusionalisme yang merupakan sejumlah ketentuan hukum yang tersusun secara sistematis untuk menata dan mengatur struktur dan fungsi-fungsi negara. ${ }^{6}$ Mengenai atribusi, delegasi dan mandat ini H.D. Van Wijk/Willem Konijnenbelt mendefinisikan sebagai berikut:

1. Atribusi adalah kewenangan yang diperoleh oleh organ pemerintahan secara langsung dari peraturan perundangundangan;

2. Delegasi adalah pelimpahan wewenang darisatuorganpemerintahankepadaorgan pemerintahan lainnya;

3. Mandatterjadiketikaorganpemerintahan mengizinkan kewenangannya dijalankan oleh organ lain atas namannya. ${ }^{7}$

\section{Teori Pengawasan}

Sebagai lembaga perwakilan daerah DPRD memiliki fungsi legislasi, fungsi pengawasan, dan fungsi anggaran. Keberadaannya sangat penting untuk mendorong terciptanya suatu pemerintahan

\footnotetext{
Ibid hlm 104

${ }^{6}$ Jazim Hamidi dan Malik,Hukum Perbandingan Konstitusi, Prestasi Pustaka Publisher, Jakarta, 2008 Hlm. 11

Ridwan HR, Op. cit hal. 105
} 
daerah yang baik. Etika merupakan salah satu instrumen penting dalam penegakkan aturan-aturan hukum. Standar perilaku sebagai dasar pengawasan dari Badan Kehormatan, maka DPRD diwajibkan untuk menyusun kode etik guna menjaga martabat dan kehormatan anggota DPRD dalam menjalankan tugas dan wewenangnya. Kode etik paling tidak harus meliputi. ${ }^{8}$

a. Pengertian kode etik

b. Tujuan kode etik

c. Pengaturan sikap, tata kerja, tata hubungan antara para penyelenggaraan pemerintahan daerah dan antar anggota DPRD dan pihak lainnya

d. Hal yang baik dan sepantasnya dilakukan oleh anggota DPRD

e. Etika dalam penyampaian pendapat, tanggapan, jawaban, sanggahan

f. Sanksi dan rehabilitasi.

\section{Teori Efektivitas Hukum}

Penegakan hukum adalah upaya untuk memenuhi tujuan hukum, menurut Martokusumo, tujuan pokok hukum adalah mencepatkan tatanan masyarakat yang tertib, menciptakan ketertiban dan keseimbangan karena dengan tercapainya ketertiban di masyarakat, diharapkan kepentingan manusia akan dapat terlindungi. ${ }^{9}$

Menurut Soerjono Soekanto juga menyatakan, bahwa hukum atau peraturan benar-benar berfungsi senantiasa dikembalikan pada paling sedikit 4 (empat) faktor, yaitu : ${ }^{10}$

a. Hukum atau peraturan itu sendiri.

b. Petugas yang menegakkannya.

\footnotetext{
${ }^{8}$ Suriansyah Murhani, Aspek Hukum Pengawasan Pemerintah Daerah, Laksbang Mediatama, 2008, Yogyakarta, hlm. 81

${ }^{9}$ Sudikno Mertokusumo, Mengenal Hukum (Suatu Pengantar), Liberty,jogjakarta,1986, hal.57

${ }^{10}$ Ibid
}

c. Fasilitas yang diharapkan mendukung pelaksanaan hukum.

d. Warga masyarakat yang terkena ruang lingkup dari peraturan hukum tersebut.

Untuk berfungsinya hukum, keempat komponen pendukung tersebut harus saling mendukung, karena penegakan hukum di suatu Negara merupakan suatu proses yang interaktif artinya hasil penegakan hukum itu janganlah diterima sebagai hasil karya dari para penegak hukum sendiri, melainkan suatu hasil bekerja nya proses saling mempengaruhi diantara berbagai komponen yang mendukung tersebut.

\section{1)TinjauanumumBadanKehormatanDPRD Provinsi NTB}

Berdasarkan Pasal 66 ayat (2) Peraturan Dewan Perwakilan Rakyat Daerah No. 1 Tahun 2014 tentang Tata Tertib Dewan Perwakilan Rakyat Daerah provinsi NTB. Anggota Badan Kehormatan dipilih dan ditetapkan dalam rapat paripurna DPRD berdasarkan usul dari masing-masing fraksi, tiap-tiap fraksi berhak mengusulkan calon anggota Badan Kehormatan sesuai perimbangan jumlah fraksi tiap-tiap fraksi, juga apabila anggota Badan Kehormatan ditarik oleh fraksinya sebelum habis masa jabatan dalam satu periode atau pengganti antar waktu maka diadakan pemilihan ulang dalam rapat paripurna berdasarkan usulan masing-masing fraksi yang belum menempatkan anggotanya di Badan Kehormatan.

Di dalam pasal 66 ayat (2) Peraturan Dewan Perwakilan Rakyat Daerah No. 1 Tahun 2014 tentang Tata Tertib Dewan Perwakilan Rakyat Daerah provinsi NTB Juga menjelaskan Bahwa masa tugas anggota Badan Kehormatan paling lama dua setengah tahun selanjutnya akan diadakan penggantian antar waktu anggota DPRD, dalam hal penggantian antar waktu, Fraksi dapat mengusulkan kembali calon anggota DPRD pengganti antar waktu 
untuk menduduki tempat anggota Badan Kehormatan yang digantikan.

Sedangkan Tugas Badan Kehormatan yang diatur Pasal 66 Peraturan Dewan Perwakilan Rakyat Daerah Provinsi NTB Nomor 1 Tahun 2014 Tentang Tata Tertib Dewan Perwakilan Rakyat Daerah Provinsi NTB adalah sebagai berikut:

1. Mengamati, mengevaluasi disiplin, etika, dan moral para anggota DPRD dalam rangkamenjagamartabatdankehormatan sesuai dengan kode etik DPRD;

2. Meneliti dugaan pelanggaran yang dilakukan anggota DPRD terhadap Tata Tertib DPRD;

3. Melakukan penyelidikan, verifikasi,dan klarifikasi atas pengaduan pimpinan DPRD, masyarakat dan/atau pemilih;

4. Menyampaikan laporan atas keputusan badan kehormatan kepada paripurna DPRD; dan

5. Dapatmenjatuhkansanksikepadaanggota DPRD yang terbukti melanggar kode etik anggtota DPRD.

Dalam melaksanakan tugasnya, Badan Kehormatan diberikan wewenang, menurut Pasal 68 Peraturan Dewan Perwakilan Rakyat Daerah Provinsi NTB Nomor 1 Tahun 2014 Tentang Tata Tertib Dewan Perwakilan Rakyat Daerah Provinsi NTB sebagai berikut:

a) Memanggil Anggota yang bersangkutan untuk memberikan penjelasan dan pembelaan terhadap dugaan pelanggaran yang dilakukan; dan

b) Meminta keterangan pelapor, saksi, dan/atau pihak-pihak yang terkait, termasuk untuk meminta dokumen atau bukti lain.

2) Mekanisme pengaduan/pelaporanpelanggaran
Berdasarkan Peraturan Dewan Perwakilan Rakyat Daerah Provinsi NTB Nomor 1 Tahun 2014 Tentang Tata Tertib Dewan Perwakilan Rakyat Daerah Provinsi NTB Pasal 69 ayat (1) mekanisme pengaduan/pelanggaran yaitu:

a. Pengaduan/pelaporan tentang dugaan adanya pelanggaran diajukan secara tertulis kepada pimpinan DPRD disertai identitas pelapor yang jelas dengan tembusan Badan Kehormatan;

b. Pengaduan/ pelaporan sebagaimana dimaksudpadahurufadikesampingkan apabila tidak disertai dengan identitas pelapor yang jelas;

c. Pimpinan DPRD menyampaikan pengaduan/pelaporan kepada Badan Kehormatan untuk ditindaklanjuti;

d. Apabila dalam waktu 7 (tujuh) hari kerja sejak diterimanya pengaduan/ pelaporan sebagaimana di maksud pada huruf a, tidak disampaikan oleh Pimpinan DPRD, Badan Kehormatan dapat menindaklanjuti.

Terdapat ketentuan khusus mengenai pengaduan yang akan diajukan kepada Badan kehormatan seperti yang dijelaskan didalam pasal 12 ayat (1) Peraturan Dewan Perwakilan Rakyat Daerah Provinsi NTB Nomor 4 Tahun 2010 tentang Tata Beracara Badan Kehormatan Dewan Perwakilan Rakyat Daerah Provinsi NTB yaitu setelah menerima pelaporan, sekretariat melakukan verifikasi kelengkapan pelaporan meliputi:

a. identitas pengadu/pelapor meliputi:

- nama lengkap;

- tempat tanggal lahir/umur;

- jenis kelamin;

- pekerjaan;

- kewarnegaraan;

- alamat lengkap/domisili

b. dilampiri fotocopy dokumen identitas kependudukan yang sah berupa kartu 
Tanda Penduduk (KTP) atau bukti identitas lain yang sah dan masih berlaku.

c. Identitas Teradu/Terlapor, meliputi:

- Nama lengkap

- Partai Politik/fraksi

d. Uraian peristiwa terjadinya dugaan pelanggaran yang dilaporkan;

e. Bukti-bukti yang berkaitan dengan fakta/ peristiwa yang dilaporkan

\section{3) Verifikasi}

Sekretariat Badan Kehormatan DPRD melakukan verifikasi terhadap unsur administrasi dan materi aduan dengan dibantu tenaga ahli. Sekretariat Badan Kehormatan melakukan verifikasi terhadap unsur administratif, sedangkan tenaga ahli melakukan verifikasi terhadap unsur materi pengaduan. Pengaduan telah dinyatakan lengkap secara administratif dan memenuhi ketentuan Tata Tertib, Kode Etik dan Tata Beracara, maka Pengaduan diterima oleh Sekretariat dan kepada Pengadu diberikan surat tanda penerimaan Pengaduan dan selanjutnya diajukan dalam Rapat Badan Kehormatan. ${ }^{11}$

Berdasarkan pasal 12 ayat $(5,6,7$, 8) Peraturan Dewan Perwakilan Rakyat Daerah Provinsi NTB Nomor 4 Tahun 2010 Tentang Tata Beracara Badan Kehormatan DPRD Provinsi NTB. Dalam hal Pengaduan belum lengkap, Sekretariat memberitahukan secara tertulis kepada pengadu tentang kekuranglengkapan pengaduan, dan pengadu diminta melengkapi pengaduan dalam waktu paling lambat 6 (enam) hari kerja sejak diterimanya surat pemberitahuan kekuranglengkapan pengaduan. Apabila kelengkapan pengaduan tidak dilengkapi, maka pengaduan tidak diregistrasi dalam buku register, pelaporan atau pengaduan yang dinyatakan tidak diterima tidak dapat

${ }^{11}$ Peraturan Dewan Perwakilan Rakyat Daerah No. 4 Tahun 2010 Pasal 12, tentang Tata Tertib Dewan Perwakilan Rakyat Daerah Provinsi NTB diajukan kembali kecuali ditemukan buktibukti baru. Pengaduan dinyatakan gugur apabila terlapor meninggal dunia, telah mengundurkan diri, atau ketentuan yang diduga dilanggar dinyatakan tidak berlaku. Pelaporan yang dinyatakan tidak diterima dan setelah jangka waktu paling lambat enam hari tidak dipenuhi, tidak dapat diajukan kembali, kecuali ditemukan buktibukti baru. ${ }^{12}$

\section{4). Penyelidikan}

Setelah semua pengaduan diverifikasi oleh sekretariat Badan Kehormatan dan tenaga ahli Badan Kehormatan, selanjutnya Badan Kehormatan melakukan penyelidikan. Dalam hal ini Badan Kehormatan memanggil pengadu dan terlapor. Penyelidikan dilakukan guna mencari kebenaran dari suatu pengaduan atau kebenaran Alat Bukti yang didapatkan dalam Sidang Badan Kehormatan. Badan Kehormatan memutuskan untuk menindaklanjuti, atau tidak menindaklanjuti pengaduan berdasarkan kelengkapan data atau bukti-bukti pengaduan. Selain memutuskan untuk menindaklanjuti pengaduan berdasarkan kelengkapan data atau bukti-bukti pengaduan, Badan Kehormatan juga dapat menindaklanjuti pelanggaran yang tidak memerlukan pengaduan, pelanggaran yang tidak memerlukan pengaduan adalah pelanggaran atas ketidakhadiran Anggota DPRD dalam Rapat-Rapat DPRD yang menjadi kewajibannya. ${ }^{13}$

\section{5).Pelaksanaan Keputusan Badan Ke- hormatan DPRD}

Berdasarkan Pasal 45 Peraturan Dewan Perwakilan Rakyat Daerah Provinsi NTB Nomor 1 Tahun 2014 Tentang Tata Tertib Dewan Perwakilan Rakyat Daerah Provinsi NTB , rapat pengambilan keputusan Badan Kehormatan dipimpin oleh ketua atau

\footnotetext{
${ }^{12}$ Ibid

${ }^{13}$ Wawancara dengan H. Syamsuddin Majid, Anggota Badan Kehormatan DPRD Provinsi NTB, tanggal 12 Mei 2016
} 
wakil ketua Badan Kehormatan, rapat pengambilan keputusan Badan Kehormatan dilakukan secara tertutup dan rahasia, dalam hal Ketua Badan Kehormatan berhalangan memimpin sidang, rapat pengambilan keputusan dipimpin oleh Wakil Ketua Badan Kehormatan, dalam hal Ketua Badan Kehormatan berhalangan hadir, sidang dipimpin oleh salah satu anggota yang ditunjuk oleh rapat anggota.

Mekanisme Pengambilan keputusan Badan Kehormatan berdasarkan hasil wawancara dengan informan dan peraturan tata tertib DPRD Provinsi NTB akan penulis jelaskan sebagai berikut:

Pembuktian menjadi dasar pengambilan keputusan dalam sidang verifikasi. Proses pengambilan keputusan adalah verifikasi terhadap risalah atau transkrip, rekaman rapat dan/atau sidang verifikasi, pendapat etik seluruh pimpinan dan anggota Badan Kehormatan. Badan Kehormatan menetapkan keputusan hasil penyelidikan dan verifikasi. Sebelum mengambil keputusan, seluruh hasil sidang rapat Badan Kehormatan diverifikasi dan hasilnya ditulis dalam lembar keputusan.

1. Rapat pengambilan keputusan Badan Kehormatan didasarkan atas:

a. Asas kepatutan;

b. Fakta-fakta dalam hasil sidang verifikasi;

c. Fakta-fakta dalam pembuktian;

d. Fakta-fakta dalam pembelaan; dan

e. Tata tertib dan kode etik

Isi putusan terkait dengan terbukti atau tidak nya suatu pelanggaran, disertai pemberian sanksi atau rehabilitasi. Selanjutnya hasil keputusan Badan Kehormatan disampaikan kepada pimpinan DPRD. Keputusan Badan Kehormatan bersifat final dan mengikat.
2. Jenis Amar Putusan Badan Kehormatan:

a. Menyatakan Teradu tidak terbukti melanggar; atau

b. Menyatakan Teradu terbukti melanggar

3. Rehabilitasi dan Sanksi.

Jikatidakterbuktiterjadipelanggaran, dilakukan rehabilitasi terhadap teradu. Dalam hal terbukti terjadi pelanggaran, keputusan disertai dengan sanksi seperti yang dijelaskan dalam Pasal 70 ayat (2) Peraturan DPRD Provinsi NTB Nomor 1 Tahun 2014 Tentang Tata Tertib Dewan Perwakilan Rakyat Daerah Provinsi NTB berupa :

a. Teguran lisan;

b. Teguran tertulis;

c. Diberhentikan sebagai anggota sesuai ketentuan peraturan perundangundangan.

4. Sanksi pelanggaran Etik DPRD

Dalam hal pelanggaran tidak terbukti, Badan Kehormatan DPRD menyampaikanrehabilitasiyangbersangkutankepada pimpinanDPRDdanditembuskankepada pimpinan fraksi bersangkutan. Rehabilitasi yang dimaksud diumumkan dalam rapat paripurna DPRD yang pertama sejak diterimanya keputusan Badan Kehormatan DPRD oleh pimpinan DPRD dan dibagikan kepada seluruh anggota DPRD.

Dalam hal pelanggaran terbukti, pelaksanaansanksikepadateradumasingmasing dilakukan sebagai berikut:

a. Sanksi berupa teguran lisan, teguran tertulis, disampaikan oleh pimpinan DPRDkepadaanggotayangbersangkutan kepada pimpinan fraksi dan pimpinan partai politik yang bersangkutan secara tertulis.

b. Sanksi berupa pemberhentian sebagai anggota DPRD, di disampai- 
kan oleh Badan Kehormatan kepada pimpinan DPRD dan ditembuskan kepada pimpinan partai politik yang bersangkutan. Pemberhentian yang dimaksud dibacakan di dalam rapat paripurna DPRD, sejak diterimanya keputusan Badan Kehormatan DPRD oleh pimpinan DPRD dan pemberhentian tersebut disampaikan oleh pimpinan DPRD kepada Gubernur untuk diresmikan dengan Keputusan Menteri Dalam Negeri.

\section{6). Rapat Badan Kehormatan}

Badan Kehormatan dalam rapat dan sidang perkara bisa dilakukan baik didalam maupun di luar lingkungan parlemen. Badan Kehormatan memutuskan untuk menindaklanjuti, atau tidak menindaklanjuti pengaduan berdasarkan kelengkapan data atau bukti-bukti pengaduan. Selain memutuskan untuk menindaklanjuti pengaduan berdasarkan kelengkapan data atau bukti-bukti pengaduan, Badan Kehormatan dapat menindaklanjuti atau tidak menindaklanjuti pelanggaran yang tidak memerlukan pengaduan.

7). Pemberhentian Antar waktu anggota DPRD

Dalam hal pemberhentian antar waktu Tehadap anggota DPRD diatur dalam pasal 355 Undang-undang Nomor 17 Tahun 2014 Tentang Majelis Permusyawaratan Rakyat, Dewan Perwakilan Daerah, dan Dewan Perwakilan Rakyat Daerah yang berbunyi:

1. Anggota DPRD provinsi berhenti antarwaktu karena:

a. meninggal dunia;

b. mengundurkan diri; atau

c. diberhentikan

2. Anggota DPRD provinsi diberhentikan antarwaktu sebagaimana dimaksud pada ayat (1) huruf c, apabila:

a. tidak dapat melaksanakan tugas secara berkelanjutan atau berhalangan tetap sebagai anggota DPRD provinsi selama 3 (tiga) bulan berturut-turut tanpa keterangan apa pun;

b. melanggar sumpah/janji jabatan dan kode etik DPRD provinsi;

c. dinyatakan bersalah berdasarkan putusan pengadilan yang telah memperoleh kekuatan hukum tetap karena melakukan tindak pidana yang diancamdenganpidanapenjara5(lima) tahun atau lebih;

d. tidak menghadiri rapat paripurna dan/ atau rapat alat kelengkapan DPRD provinsi yang menjadi tugas dan kewajibannya sebanyak 6 (enam) kali berturut-turut tanpa alasan yang sah;

e. diusulkan oleh partai politiknya sesuai dengan ketentuan peraturan perundang-undangan;

f. tidak lagi memenuhi syarat sebagai calon anggota DPRD provinsi sesuai dengan ketentuan peraturan perundang-undangan mengenai pemilihan umum;

g. melanggar ketentuan larangan sebagaimana diatur dalam UndangUndang ini;

h. diberhentikan sebagai anggota partai politik sesuai dengan ketentuan peraturan perundang-undangan; atau

i. menjadi anggota partai politik lain.

\section{Implementasi Tugas dan Kewenangan Badan Kehormatan DPRD Provinsi NTB}

Badan Kehormatan dibentuk dengan tujuan utama menjaga citra DPRD sebagai sebuah lembaga yang terhormat dari anggota DPRD yang tidak beretika. Badan Kehormatan ada untuk mencegah masyarakat apatis dan tidak respek terhadap DPRD, gara-gara anggota DPRD sendiri yang tidak mampu menjaga citra sebagai lembaga 
terhormat. Pada periode-periode sebelum Badan Kehormatan dibentuk, banyak anggota DPRD melakukan hal-hal yang tidak terpuji, sehingga menimbulkan citra jelek di masyarakat. Kemudian dengan dibentuknya Badan Kehormatan, sehingga secara internal ada yang mengawasi. Sebagaimana yang dijelaskan oleh Martokusumo, bahwa tujuan pokok hukum adalah mencepatkan tatanan masyarakat yang tertib, menciptakan ketertiban dan keseimbangan karena dengan tercapainya ketertiban di masyarakat, diharapkan kepentingan manusia akan dapat terlindungi. ${ }^{14}$

Dalam melaksanakan tugas, wewenang, dan kewajibannya, Berdasarkan Pasal 143 Peraturan Dewan Perwakilan Rakyat Daerah Provinsi NTB Nomor 1 Tahun 2014 Tentang Tata Tertib Dewan Perwakilan Rakyat Daerah Provinsi NTB, anggota DPRD harus menaati Kode Etik DPRD. Kode Etik DPRD adalah suatu ketentuan etika perilaku sebagai acuan kinerja anggota DPRD dalam melaksanakan tugasnya. Kode Etik meliputi norma-norma atau aturanaturan yang merupakan kesatuan landasan etik atau filosofis dengan peraturan sikap, perilaku, ucapan, tata kerja, tata hubungan antar Lembaga Pemerintahan Daerah dan antar anggota serta antara anggota DPRD dengan pihak lain mengenai hal-hal yang diwajibkan, dilarang atau tidak patut dilakukan oleh anggota DPRD.

Adapun tentang Peraturan Kode Etik Peraturan Dewan Perwakilan Rakyat Daerah Provinsi NTB Nomor 1 Tahun 2014 Tentang Tata Tertib Dewan Perwakilan Rakyat Daerah Provinsi NTB Semua anggota DPRD diharapkan dalam melaksanakan tugas, wewenang, dan kewajibannya didasarkan dan mengacu pada Kode Etik DPRD, sehingga tujuan dari dibentuknya Kode Etik dapat tercapai, diharapkan juga dengan adanya Badan Kehormatan dapat membantu anggota DPRD

${ }^{14}$ Martokusumo, Op cit hal.57 dalam melaksanakan tugas, wewenang dan kewajibannya dan dapat mempertanggungjawabkannya kepada pemilih, masyarakat dan negara.

Terkait dengan penyelesaian pelanggaran kode etik oleh Badan Kehormatan di DPRD Provinsi NTB. Busrah Hasan menyatakan: ${ }^{15}$

1. Apabila ada anggota DPRD yang tidak patuh atau melakukan pelanggaran terhadap Kode Etik DPRD tindakan pertama yangdilakukanBadanKehormatanadalah melakukandenganmengingatkananggota DPRD yang melakukan pelanggaran.

2. Apabila anggota DPRD tidak mengindahkan, maka Badan Kehormatan akan melayangkan teguran melalui Fraksi.

3. Apabila dengan teguran juga tidak digubris, maka Badan Kehormatan akan memproses dan memberi sanksi sesuai dengan Peraturan yang ada di DPRD Provinsi NTB.

Dalam melaksanakan tugasnya, Badan Kehormatan bekerja secara normatif/sesuai dengan tata peraturan yang berlaku di DPRD Provinsi NTB yaitu sesuai dengan Peraturan Tata Tertib DPRD Provinsi NTB. Dengan kata lain apabila ada anggota DPRD yang melakukan pelanggaran terhadap Kode Etik DPRD, maka Badan Kehormatan menunggu adanya pengaduan atas pelanggaran yang dilakukan anggota DPRD baik dari Pimpinan DPRD, masyarakat, dan atau pemilih. Sedangkan dalam hal pelanggaran yang dapat ditindak langsung oleh Badan Kehormatan adalah pelanggaran ketidakhadiran anggota DPRD dalam rapatrapat DPRD yang menjadi kewajibannya.

Setelah ada pengaduan, maka Badan Kehormatan akan meneliti dan memeriksa pengaduan tersebut, Selanjutnya Badan Kehormatan membuat kesimpulan hasil penelitian dan pemeriksaan dan me-

15 Wawancara dengan H. Busrah Hasan, Ketua Badan Kehormatan DPRD Provinsi NTB, tanggal 26 April 2016 
nyampaikannya kepada Pimpinan DPRD. Dan pada tahap akhir, Badan Kehormatan menetapkan sanksi atau rehabilitasi terhadap anggota yang dilaporkan sesuai yang tertera dalam kode etik DPRD Provinsi.

Dalam hal pengaduan Badan Kehormatan DPRD Provinsi NTB, periode 2014-2016 pernah mendamaikan Wakil Ketua DPRD NTB, MF dan Ketua Badan Pembentukan Perda (Baperda) NTB, B. Ispie Rupaeda. B.IR melaporkan MF ke Badan Kehormatan lantaran pemberitaan di salah satu media yang terkesan menyudutkan Baperda DPRD NTB.

Menindaklanjuti laporan tersebut, Badan Kehormatan DPRD NTB memanggil pihak teradu dan pengadu, Badan Kehormatan mengadakan rapat yang waktu itu, dilaksanakan di luar kantor DPRD, berdasarkan keterangan dari keduanya, Badan Kehormatan memutuskan untuk mendamaikan karena $\mathrm{MF}$ tidak mengakui perkataan nya di media tersebut, berdasarkan keterangan tersebut Badan Kehormatan menyimpulkan bahwa kasus ini hanya miskomunikasi saja dan diputuskan untuk mendamaikan keduanya karena menurut ketua Badan Kehormatan mendamaikan juga merupakan salah satu keputusan akhir dari persoalan yang dilaporkan ke Badan Kehormatan.

Menurut penulis seharusnya Badan Kehormatan memanggil wartawan yang menulis berita tersebut sebagai saksi, apakah memang benar MF tidak mengeluarkan pernyataan tersebut ke media, agar kedepannya tidak terulang kembali kejadian tersebut diatas, karena kalau memang benar terbukti pernyataan MF di media tersebut, tentu saja saling memfitnah di berbagai media akan di anggap biasa oleh anggota DPRD yang lain karena tidak takut lagi akan dilaporkan ke Badan Kehormatan.

Pada dasarnya apabila ada hal-hal yang tidak sesuai dengan Kode Etik maka Badan Kehormatan seharusnya bisa langsung mengingatkan, karena Badan Kehormatan fungsinya untuk itu. Kewenangan Badan Kehormatan bisa sampai memutuskan pemberhentian anggota DPRD yang melakukan pelanggaran, tetapi eksekusinya tetap pada Pimpinan DPRD. Menurut ketua badan kehormatan DPRD Provinsi NTB, Badan Kehormatan lebih mengharapkan kedewasaan rekan-rekan sesama anggota DPRD untuk menyadari kedudukannya, daripada beraksi untuk mengingatkan anggota DPRD yang melakukan pelanggaran.

Dalam wawancara dengan Ketua Badan Kehormatan Busrah Hasan juga menambahkan Apabila ada pelanggaran, tetapi baik dari Pimpinan DPRD, masyarakat dan atau pemilih tidak menyampaikan pengaduan maka Badan Kehormatan juga tidak akan memprosesnya. Karena Badan Kehormatan bekerja secara normatif. Jadi bisa dikatakan kinerja Badan Kehormatan akan baik jika ada dukungan dari Pimpinan DPRD, masyarakat dan atau pemilih.

Seperti Pada Kamis 3 Maret 2016, Wakil Ketua DPRD Nusa Tenggara Barat MH mengatakan didepan wartawan akan melaporkan sesama koleganya di DPRD, MF ke Badan Kehormatan, dikarenakan MF menudingnya sebagai pembohong di sejumlah media.

Menanggapi hal itu, Ketua Badan Kehormatan DPRD Nusa Tenggara Barat, Busrah Hasan mengatakan kepada sejumlah media "Kami siap menindaklanjuti laporan anggota karena sudah merupakan tugas dan kewajiban Badan Kehormatan untuk menuntaskan masalah," jika sudah ada laporan atau pengaduan, baik secara tertulis maupun lisan, Badan Kehormatan pasti akan menindaklanjuti nya. Namun sejauh ini laporan dari $\mathrm{MH}$ terhadap Wakil Ketua DPRD MF belum ada Kalau ada pengaduan atau laporan, pasti kami proses. Karena sudah merupakan tugas dan kewajiban Badan Kehormatan. 
Dilihat dari penjelasan diatas Badan kehormatan seharusnya memanggil kedua anggota DPRD tersebut, meskipun tidak adanya pengaduan dari pihak yang bersangkutan karena salah satu kewajiban DPRD seperti yg dijelaskan didalam tata tertib DPRD adalah menjaga hubungan baik sesama anggota. Jadi sudah Seharusnya Badan Kehormatan memberikan nasehat sebagai penengah karena memang tugas Badan Kehormatan adalah sebagai lembaga yang mengevaluasi etika DPRD. Karena kedua anggota DPRD tersebut tidak melaksanakan kewajibannya, jadi sudah selayaknya badan kehormatan memberikan teguran, selain itu juga, agar tidak menimbulkan konflik yang berkepanjangan apalagi hal tersebut diketahui media.

Sedangkan dalam hal pelanggaran yang tidak memerlukan pengaduan yaitu pelanggaran kode etik yang dilakukan oleh anggota DPRD yang sudah diketahui secara luas oleh masyarakat melalui media, selain itu, Dalam Tata Tertib diatur bahwa pelanggaran kode etik yang tidak memerlukan pengaduan Badan Kehormatan mengambil inisiatif untuk meminta daftar kehadiran agar ketidakdisiplinan terlihat secara faktual dan akurat Dalam proses persidangan.

Pada tanggal 4 mei 2016, seluruh anggota DPRD Nusa Tenggara barat diwajibkan melakukan test urine dari 43 daftar anggota DPRD yang hadir dalam sidang paripurna DPRD NTB, Empat anggota DPRD yang hadir tetapi meninggalkan sidang paripurna di saat pelaksanaan tes urine dari BNN Provinsi NTB. Ketua Badan Kehormatan mengatakan tugas Badan Kehormatan hanya bersifat mengecek absensi anggota DPRD saat pelaksanaan sidang paripurna. Badan Kehormatan meminta agar pemimpin DPRD bersikap tegas dan meminta empat anggota tersebut untuk melakukan test susulan langsung ke BNN Provinsi NTB.

Menurut penulis seharusnya Badan Kehormatan lebih tegas dalam menindak empat anggota DPRD yang kabur saat pelaksanaan test urine tersebut dengan cara memanggil dan meminta keterangan keempat nya bukan hanya meminta pimpinan DPRD untuk memberikan himbauan atau peringatan, karena Badan kehormatan mempunyai hak untuk itu.

Berdasarkan hasil wawancara dan data yang peneliti peroleh dari DPRD Provinsi NTB, bahwa Implementasi kewenangan Badan Kehormatan dalam menegakkan Kode etik anggota DPRD Provinsi NTB, belum maksimal, karena kewenangan yang besar seperti yang diamanatkan dalam peraturan tata tertib DPRD Provinsi NTB, kepada Badan Kehormatan, tidak membuat Badan Kehormatan cukup kuat dalam melaksanakan kewenangannya, Pimpinan DPRD dan Fraksi ikut berperan dalam penyanderaan kewenangan Badan Kehormatan, Badan Kehormatan harus terlebih dahulu melaporkan kasus pelanggaran etika kepada Pimpinan DPRD dan Fraksi. dikaitkan dengan hambatanhambatan yang dihadapi Badan Kehormatan dalam menjalankan Kewenangannya yaitu:

1. Hukum atau peraturan itu sendiri

Penegakan hukum adalah upaya untukmemenuhitujuanhukum, menurut Martokusumo, tujuan pokok hukum adalah menciptakan tatanan masyarakat yang tertib, menciptakan ketertiban dan keseimbangan karena dengan tercapainya ketertiban di masyarakat, diharapkan kepentingan manusia akan dapat terlindungi. PentingnyaPeraturanhukum untuk ditegakkan bukan hanya untuk menuntun tindakan manusia, melainkan juga lebih bersifat menjaga agar manusia tetap berada dalam batas-batas tertentu, Sebagaimana diketahui dalam hal ini, misalnya Badan Kehormatan ada dan dibentuk dalam suatulembagaperwakilan rakyat (BK DPR/DPRD), yang tugasnya mengamati, mengevaluasi disiplin, etika dan moral anggota DPRD yang tujuannya 
adalah menjaga martabat, kredibilitas dan kehormatan DPRD. Selain itu, Badan Kehormatan juga mempunyai kewenangan untuk memanggil anggota DPRD untuk memberikan penjelasan dan pembelaan terhadapdugaan pelanggaranyangdilakukan oleh anggota DPRD terhadap Peraturan Perundang-undangan, Kode Etik maupun Peraturan Tata Tertib Dewan.

Terkait kewenangannya tersebut Badan Kehormatan DPRD Provinsi NTB Dalam mengambil keputusan Badan Kehormatan dibatasi peraturan tentang tata beracara misalnya sepertipengaduan yang masuk ke Badan Kehormatan tanpa adanya identitas dari pengadu, maka pengaduan tersebut hanya dijadikan catatan oleh badan kehormatan. Pengaduan harus memuat identitas pengadu, identitas teradu, Hal tersebut membuat Badan Kehormatan sulit untuk menindak anggota DPRD yang benar-benar melanggar tata tertib ataupun kode etik, ketika muatan dalam pengaduan tesebut tidak lengkap.

\section{Petugas yang menegakkannya}

Menyangkut kepribadian dan mentalitas penegak hukum, bahwa selama ini ada kecendrungan yang kuat dikalangan masyarakatuntukmengartikanhukumsebagaipetugasataupenegakhukum, artinya hukum diidentikkan dengan tingkah laku nyata petugas atau penegak hukum. Sayangnya dalam melaksanakan wewenang nya sering timbul persoalan karena sikap atau perlakuan yang dipandang melampaui wewenang atau perbuatan lainnya yangdianggapmelunturkancitradanwibawapenegakhukum, halinidisebabkanoleh kualitas yang rendah dan aparat penegak hukum tersebut. Berkaitan dengan Badan Kehormatan, Dalam melaksanakan kewenangannyaBadanKehormatanbisasaja dipengaruhi oleh pihak luar, mengingat Badan Kehormatan yang merupakan perwakilan fraksi dan orang yang dipercayai fraksi serta bisa kapan saja ditarik oleh fraksi nya.

Mengingat hal itu, adanya kepentingan masing-masing anggota Badan Kehormatan berdasarkan kepentingan fraksi nya yang juga ikut berperan dalam penyanderaan kewenangan Badan Kehormatan secara tidak langsung. Dalam hal ini Badan Kehormatan harus terlebih dahulu melaporkan hasil keputusan kasus pelanggaran etika kepada Fraksi. Dengan Adanya intervensi tersebut membuat badan kehormatan dalam mengambil keputusan atau memberikan sanksi terhadap anggota DPRD yang melakukan pelanggaran sangat sulit bebas dari pengaruh partai politik. Anggota Badan Kehormatan tidak diwakili oleh semua Fraksi, hal itu berdampak pada semua persoalan yang muncul, seharusnya di Badan Kehormatan ada keterwakilan semua fraksi, salah satu bentuk pencegahan bisa dilakukan melalui fraksi yang selalu mengingatkan bila anggota fraksinya yang telah melakukan pelanggaran.

3. Warga masyarakat yang terkena ruang lingkup dari peraturan hukum tersebut.

Penegak hukum berasal dari masyarakat dan bertujuan untuk mencapaikedamaiandidalammasyarakat. Oleh karena itu, dipandang dari sudut tertentu, maka masyarakat dapat mempengaruhi penegakan hukum. Apabila warga masyarakat sudah mengakui hak dan kewajiban mereka, maka mereka juga akan mengetahui aktivitas-aktivitas penggunaan upaya hukum untuk melindungi, memenuhi dan mengembangkan kebutuhankebutuhan mereka dengan aturan yang ada. Setiap warga masyarakat atau kelompok diharapkan sedikit banyaknya mempunyai kesadaran hukum, yaitu kepatuhan hukum yang tinggi. Terkait 
dengan Badan Kehormatan. Adapun menjadi salah satu faktor penghambat dalam penegakan hukum oleh Badan Kehormatan diDPRD Provinsi NTByaitu tidak adanya pengaduan dari masyarakat, BusrahHasanmenjelaskan"bahwaBadan Kehormatantidakbisamengawasianggota DPRD sepenuhnya, mengingat anggota Badan Kehormatan juga memiliki tugas lain sebagai anggota DPRD.

\section{SIMPULAN}

1. Implementasi kewenangan Badan Kehormatan dalam menegakkan Kode etik anggota DPRD Provinsi NTB, belum maksimal, karena kewenangan yang besar seperti yang diamanatkan dalam peraturan tata tertib DPRD Provinsi NTB, kepada Badan Kehormatan, tidak membuat Badan Kehormatan cukup kuat dalam melaksanakan kewenangannya, Pimpinan DPRD dan Fraksiikutberperan dalam penyanderaan kewenangan Badan Kehormatan, Badan Kehormatan harus terlebih dahulu melaporkan kasus pelanggaranetikakepadaPimpinanDPRD dan Fraksi.

2. Kendala-kendala yang dihadapi Badan Kehormatan yaitu:

a. Dibatasi peraturan tentang tata beracara, pengaduan yang masuk ke Badan Kehormatan dikesampingkan apabila tidak disertai identitas yang jelas.

b. Dalam melaksanakan kewenangannya Badan Kehormatan bisa saja dipengaruhi oleh pihak luar, mengingat Badan Kehormatan yang merupakan perwakilan fraksi dan bisa kapan saja ditarik oleh fraksinya.

c. Kurangnya dukungan dari masyarakat, hal ini terlihat dari Tidak adanya pengaduan dari masyarakat.

\section{DAFTAR PUSTAKA}

\section{A. Buku}

524 IUS Kajian Hukum dan Keadilan
Hendrojono, Sosiologi Hukum, Pengaruh Perubahan Masyarakat dan Hukum, Srikandi, Jakarta, 2005.

Harjono, Penelitian Hukum pada Kajian Hukum Murni, dalam Joni Ibrahim, Teori dan Metode Penelitian Hukum Normatif, Banyumedia Publishing, Malang, 2005.

Jimly Asshiddiqie. 2010. Konstitusi dan Konstitusionalisme Indonesia. Jakarta:Sinar Grafika.

Jimly Asshiddiqie. 2011. Pengantar Ilmu Hukum Tata Negara. Jakarta: Rajawali Pers.

Miriam Budiarjo. 2010. Dasar-Dasar ilmu Politik. Edisi Revisi Cetakan Keempat. Jakarta: PT Gramedia Pustaka Utama.

Mochtar Kusumaatmadja. 1995. Fungsi dan Perkembangan Hukum dalam Pembangunan Nasional. Bandung: Bina Cipta.

Mukhtie Fadjar. 2005. Tipe Negara Hukum. Malang: Banyumedia Publishing.

Ni'matul Huda. 2011. Hukum Tata Negara Indonesia. Jakarta: Rajawali Pers.

Ridwan HR. 2006. Hukum Administrasi Negara, Jakarta: PT Raja Grafindo persada.

Rusadi Kantaprawira. 1998. Hukum dan kekuasaan, Yogyakarta: Universitas Islam Indonesia.

Suriansyah Murhani, Aspek Hukum Pengawasan Pemerintah Daerah, Laksbang Mediatama, 2008, Yogyakarta,

Sudikno Mertokusumo, Mengenal Hukum (Suatu Pengantar), Liberty,jogjakarta, 1986.

Soekanto, Soerdjono, factor-faktor yang mempengaruhi penegakan hukum, Raja Grafindo, Jakarta, 1983.

Soekanto, dalam Bambang sungkono, 
Nurmadiah| Implementasi Kewenangan Badan Kehormatan DPRD Dalam Penegakan Kode Etik.

Hukum dan Kebijaksanaan Publik, Sinar Grafika, Jakarta, 1994.

Soemitro R.H, Permasalahan Hukum di Dalam Masyarakat, Alumni, Bandung, 1980.

Satjipto Raharjo, Ilmu Hukum, citra Aditya Bakti, Bandung, 1990.

Soekanto Soerjono, Beberapa Aspek SosioYuridis Masyarakat, Alumni, Bandung, 1983.

Selo Sumardjan dalam Soekanto, Sosiologi

Hukum: Pengaruh Perubahan Masyarakat dan Hukum, Srikandi, Jakarta, 2005.

Soekanto Soerjono, Kesadaran Hukum Dan Kepatuhan Hukum, Rajawali, Jakarta, 1982.

Titik Triwulan Tutik. 2010. Pengantar Hukum Tata Usaha Negara Indonesia. Jakarta: Prestasi Pustaka Publisher.

W. Riawan Tjandra. 2008. Hukum Administrasi Negara. Yogyakarta: Penerbit Universitas Atma jaya Yogyakarta.

\section{B. Peraturan Perundang- Undangan}

Indonesia, Undang-Undang Dasar Negara Republik Indonesia Tahun 1945

Indonesia, Undang-Undang tentang Majelis Permusyawaratan Rakyat, Dewan Perwakilan Daerah, dan Dewan perwakilan Rakyat Daerah, UU No.17 Tahun 2014, LN No.182 Tahun 2014, TLN No.5568

Peraturan Dewan Perwakilan Rakyat Daerah No. 1 Tahun 2014, tentang Tata Tertib Dewan Perwakilan Rakyat Daerah provinsi NTB

\section{Internet}

http://www.republika.co.id/berita/ nasional/politik/14/08/13/na8i8c3169-anggota-dprd-diduga-terjeratkorupsi/ Diakses pada 29 januari
2016

http://lombokini.com/salah-seoranganggota-dprd-propinsi-ntbditetapkan-sebagai-tersangkakasus-bansos/ Diakses pada 29 januari 2016

www.okezone.com/09/04/2015/KronologiAdu-jotos-Anggota-Dewan-KomisiVII. Diakses pada sabtu 13 februari 2016 